\title{
Interdisciplinarity favours Human Rights
}

\author{
Daniel Stoecklin \\ University of Geneva, Switzerland
}

Submission: June 03, 2019; Published: June 25, 2019

*Corresponding author: Daniel Stoecklin, Associate Professor, Centre for Children's Rights Studies, University of Geneva, Switzerland

\section{Opinion}

Is there a link between interdisciplinarity and human rights? A simple example shows that the answer is obviously yes. Let's take the right to be heard enshrined in article 12 of the UN Convention on the Rights of the Child. It's first alinea reads as follows:

"States Parties shall assure to the child who is capable of forming his or her own views the right to express those views freely in all matters affecting the child, the views of the child being given due weight in accordance with the age and maturity of the child" [1].

\section{Alinea 2 of art. 12 UNCRC specifies the proceedings:}

"For this purpose, the child shall in particular be provided the opportunity to be heard in any judicial and administrative proceedings affecting the child, either directly, or through a representative or an appropriate body, in a manner consistent with the procedural rules of national law" (Ibid).

Provided these proceedings are guaranteed, the decisionmaker exerts authoritative power by giving due weight to the views of the child according to how those views are expressed (freely), the range of matters on which these views are expressed (all matters affecting the child) and to how they evaluate maturity of the child in relation to its age. Hence, children's views are taken seriously if they seem free from the preferences of others (who might manipulate children, as in the case of parental alienation), if they obviously address issues affecting the child, and if they look "mature" enough to be considered as the expression of rationality. Besides, as the articles of the UNCRC are mutually connected, the decision must be made with the best interests of the child (art. 3 UNCRC) being a primary consideration.

The right of the child to be heard constrains all State parties to the UNCRC (all countries except the USA) to effectively guarantee this provision. Of course, the levels of compliance vary a lot because of political, economical and organizational factors. But a more fundamental question arises even when the best conditions are met to guarantee the right of the child to be heard: How can one assess the level of maturity of a child? The pragmatic way that is prevalent consists of referring to the level of rationality generally found in the child's age-group. One can base either on personal experience of interactions with children from different age groups or on credibility tests made by experts in child development. Yet, a crucial point will always remain problematic, namely the hidden "philosophy of the mind" that preside over one's explanation of maturation, and which still constitutes the "black box" of socialization theories.

Sociology offers basically two concurring ways of considering socialization and maturation, the individualistic and the holist conceptions. In the individualistic conception (the Weberian tradition), children are considered actors who actively build "reasons" to act (or to refrain from doing so) in given circumstances they learn to recognize as appropriate through logical deductions made by comparing different contexts and their prevalent norms. In the holist conception (the Durkheimian tradition), children are considered as determined by socio-cultural patterns which they actually do not notice they are taken-for-granted as long as they are not contradicted by conditions which proves them inadequate. Tenants of each conception have refined theories, with more or less empirical cases, around these paradigms. Of courses, most judges don't have the time to read sociological works... They resort to pragmatic choices based on what they consider likely and desirable. And in a way, they are right: because sociology alone does not base enough on experimentations. It offers too many speculations. It takes an interdisciplinary approach to come closer to how socialization actually works. Very interesting developments are proposed today by scientists who enrich sociology with cognitive sciences. A recent example is the thesis of Laurent Cordonier, under the supervision of Laurence Kaufmann, presented at the University of Lausanne (Switzerland), which is now published (in French) [2]. With a rare capacity to combine cognitive psychology, developmental psychology, sociology, neurosciences and even primatology, the author advocates for a view of human beings as possessing some elementary "pre-cabled" faculties that enable them to have "naïve theories" about the world almost right from the start (experimental tests made with babies comfort this view), which are then progressively nurtured and developed in quite diversified directions by social contexts. This promises tremendous enrichments of the connections, and not oppositions, between the innate and the acquired. 
Returning to our case, such interdisciplinary developments may have a very important impact on the ways we look at children's views, how we listen to their voices, and how we adapt proceedings to make them access their rights to the maximum extent possible. This points to the ethics of human well-being that is a major stake of interdisciplinarity. Sciences may contribute to children's human rights, and to human rights in general, if they are brave and strong enough to overcome the nature/culture and body/spirit dichotomies. This also depends on the politics of science, which are recursively implicated in the respect and development of human rights. And of course, it all depends on the nature of the political regimes we are able to build and defend.

\section{References}

1. Convention on the Rights of the Child (1989) Convention on the Rights of the Child. Office of the High Commissioner of Human Rights, NewYork: United-Nations.

2. Cordonier L (2018) La nature du social. L'apport ignoré des sciences cognitives (the nature of the social. The ignored contribution of cognitive sciences). Paris: Presses Universitaires de France.

\section{Your next submission with Juniper Publishers will reach you the below assets}

- Quality Editorial service

- Swift Peer Review

- Reprints availability

- E-prints Service

- Manuscript Podcast for convenient understanding

- Global attainment for your research

- Manuscript accessibility in different formats

( Pdf, E-pub, Full Text, Audio)

- Unceasing customer service

Track the below URL for one-step submission https://juniperpublishers.com/online-submission.php 